KRZYSZTOF WALCZAK

Uniwersytet Wrocławski

\title{
ROSYJSKIE BIBLIOTEKI PUBLICZNE NA TERENIE GUBERNI KALISKIEJ. PRZYCZYNEK DO DZIEJÓW BIBLIOTEKARSTWA POCZĄTKÓW XX WIEKU
}

\section{Problem}

Kształtowanie się nowoczesnego bibliotekarstwa polskiego przypada - mówiąc w dużym uproszczeniu - na drugą połowę XIX i pierwsze lata XX wieku, choć i w tym przypadku widoczne są znaczne różnice pomiędzy poszczególnymi zaborami, wynikające $\mathrm{z}$ różnych koncepcji inkorporacji ziem polskich przez państwa zaborcze. W przypadku zaboru rosyjskiego, zwłaszcza w odniesieniu do ziem Królestwa Polskiego, w skład którego wchodziła gubernia kaliska, znaczący rozwój polskich placówek bibliotecznych wiąże się ze słabnięciem potęgi imperium Romanowów w wyniku wojny rosyjsko-japońskiej 1904 roku oraz niepokojów społecznych, zapoczątkowanych wydarzeniami w początkach 1905 roku. Te dwa czynniki, pomimo krótkotrwałego ich wpływu na wewnętrzną politykę rosyjską, postrzegane są jako zaczyn wymuszonych zmian społecznych i politycznych, tak znaczących zwłaszcza dla polskiego życia społeczno-kulturalnego pierwszych lat dwudziestego stulecia ${ }^{1}$.

Proces niemal żywiołowego powstawania w tym czasie polskich bibliotek w zaborze rosyjskim jest dość dobrze udokumentowany, szczególnie w po-

${ }^{1}$ W. Jaworski, Przemiany legalnego życia społecznego $w$ Królestwie Polskim w latach 18641914, Sosnowiec 2006. 
staci licznych monografii placówek, których istnienie zostało zapoczątkowane $\mathrm{w}$ tym czasie ${ }^{2}$. Także prace syntetyzujące owe działania, a wchodzące w zakres problematyki polskiej książki pod zaborami, nie należą do rzadkości, czego przykładem są działania autorskie m.in. prof. Kazimiery Maleczyńskiej i jej fundamentalne prace, kształtujące naszą wiedzę o dziejach polskich bibliotek XIX stulecia ${ }^{3}$.

Z oczywistych względów mniej znane pozostają natomiast rosyjskie inicjatywy biblioteczne, skierowane na terenie Królestwa Polskiego m.in. do społeczności polskiej. Tej kwestii warto poświęcić nieco uwagi.

Zagadnienie obecności rosyjskiej na terenie Królestwa Polskiego dopiero w ostatnich latach zaczęło nabierać znaczenia w literaturze bibliologicznej, choć problem ten jest znacznie szerszy i dotyczy także literatury historycznej w ogóle. Zwłaszcza teren Królestwa Polskiego, z jego śladami autonomii, datującej się od 1815 roku i stopniowo ograniczanej (zwykle w odpowiedzi na kolejne polskie powstania), stanowi wdzięczne pole obserwacji zmieniających się rosyjskich koncepcji rządzenia Polakami. Z perspektywy czasu łatwiej dostrzec rozmaite odcienie niechęci, ale także sytuacje współpracy pomiędzy nacjami - polską i rosyjską. Dostępne dziś rosyjskie źródła archiwalne i biblioteczne dostarczają niezwykle interesujących materiałów ${ }^{4}$.

\section{Archiwalia i literatura}

Dzieje rosyjskich placówek bibliotecznych, funkcjonujących na terenie guberni kaliskiej w latach 1867-1914, nie doczekały się obszerniejszego omówienia. Jednakże zachowały się ciekawe dokumenty, obrazujące owe księgozbiory i oczekujące na ich pełne wykorzystanie. Mowa tu zarówno o źródłach polskich, wytworzonych w postaci archiwaliów i zachowanych

2 Początki powstających w pierwszych latach dwudziestego stulecia bibliotek omawiane są we wszystkich niemal monografiach placówek, które - zapoczątkowane w latach 1905-1908 przetrwały do dnia dzisiejszego (np. Biblioteka Publiczna miasta stołecznego Warszawy czy Wojewódzka Biblioteka Publiczna im. Hieronima Łopacińskiego), jak i tych już dziś nieistniejących (Biblioteka i Czytelnia Publiczna im. Adama Mickiewicza w Kaliszu). Placówki te posiadają obszerną literaturę omawiającą losy poszczególnych instytucji, biblioteki te mają także swoje miejsce w pracach syntetycznych, poświęconych dziejom placówek bibliotecznych poszczególnych miast i regionów.

${ }^{3}$ Mowa tu zwłaszcza o pracy pod redakcją K. Maleczyńskiej, Z dziejów udostępniania książki w Polsce w okresie zaborów: studia i materiały, Wrocław 1985 oraz o książce popularyzującej tę tematykę tejże autorki, Książki i biblioteki w Polsce okresu zaborów, Wrocław 1987.

${ }^{4}$ Mowa tu choćby o dostępnych dzisiaj w wersji wirtualnej „Pamjatnych knižkach” poszczególnych guberni, a także „Obzorach”, informacjach statystycznych, obrazujących działalność jednostek administracyjnych m.in. Królestwa Polskiego. 
- niestety w niektórych przypadkach w stanie szczątkowym - w archiwach państwowych, jak też o udostępnianych stopniowo, zaskakująco bogatych zasobach rosyjskich, które do niedawna były niemal niedostępne dla badań naukowych. Dla Kalisza i guberni kaliskiej szczególnie cenne pozostają materiały przechowywane w archiwach państwowych Kalisza i Łodzi, a także w licznych archiwach i bibliotekach rosyjskich Petersburga i Moskwy oraz innych miast Federacji Rosyjskiej.

Wielkie znaczenie - obok archiwaliów - mają w tej mierze także źródła drukowane, a zwłaszcza ówczesna prasa, stanowiąca znakomite podłoże, ukazujące m.in. społeczne i instytucjonalne działania w sferze książki i biblioteki. I z tego względu niezwykle ważne dla dziejów XIX i początków XX wieku okazują się zasoby rosyjskie, przechowywane (z racji otrzymywania niegdyś egzemplarza obowiązkowego z terenu Królestwa Polskiego) przede wszystkim w Narodowej Bibliotece Rosji w Petersburgu ${ }^{5}$.

Obok czasopism istotne okazują się także materiały zaliczane dzisiaj częściowo do dokumentów życia społecznego. Można włączyć do nich wszelkiego rodzaju statuty i sprawozdania instytucji bibliotecznych (lub posiadających biblioteki), tłoczone w ograniczonej ilości egzemplarzy i stosunkowo rzadko zachowane do dzisiaj w zbiorach bibliotecznych.

Szczególnie istotnym dla niniejszego wystąpienia źródłem są drukowane przez cały czas istnienia guberni kaliskiej ${ }^{6}$ „Pamjatnyje knižki”. Stanowiły one rodzaj informatora osobowego i instytucjonalnego (charakterystycznego także w innym wymiarze działań dla instytucji kościelnych), odnotowującego m.in. skład osobowy urzędów administracji ogólnej i specjalnej oraz instytucji państwowych i społecznych (przede wszystkim rosyjskich, ale także polskich), funkcjonujących na terenie guberni ${ }^{7}$.

${ }^{5}$ Dobrym przykładem zasobności tej biblioteki są roczniki czasopism kaliskich, przechowywane w Petersburgu, niedostępne zaś w Polsce z powodu ich zaginięcia. Ważnym sygnałem w tej mierze jest pozyskanie w postaci digitalnej w 2013 roku przez Książnicę Pedagogiczną im. A. Parczewskiego w Kaliszu - dzięki współpracy z Narodową Biblioteką Rosji - kilku roczników „Kaliszanina”, niedostępnych od dziesięcioleci w bibliotekach polskich. Pozyskany materiał umożliwia włączenie do obiegu naukowego informacji znakomicie uzupełniających naszą wiedzę m.in. w zakresie dziejów kaliskich bibliotek XIX wieku.

${ }_{6}$ Mowa tu o tzw. drugiej guberni kaliskiej, utworzonej w 1867 roku i funkcjonującej formalnie do 1915 roku, faktycznie zaś do sierpnia 1914 roku i momentu opuszczenia Kalisza przez Rosjan.

„Pamjatnyje knižki” guberni cesarstwa rosyjskiego są w chwili obecnej przedmiotem zainteresowania Narodowej Biblioteki Rosji w Petersburgu, co umożliwia wirtualny dostęp do egzemplarzy dotychczas niedostępnych w polskich zasobach. Projekt tej biblioteki obejmuje między innymi gubernie Królestwa Polskiego, a także - naturalnie - pozostałe ziemie polskie, włączone do cesarstwa. 
Lektura „Pamjatnych knižek” przynosi zaskakującą konstatację, dotyczącą obsady stanowisk urzędniczych guberni kaliskiej. Nawet w najtrudniejszych dla żywiołu polskiego latach końca XIX stulecia, znaczna ich część (oczywiście poza stanowiskami gubernatorów i wicegubernatorów, jak również przełożonych instytucji sądownictwa, oświaty, policji i wojska) była piastowana przez Polaków, o czym świadczą choćby wymieniane w tym źródle nazwiska. Były one zapisywane fonetycznie grażdanką, co często dawało dość zabawne rezultaty. Nie ulega wątpliwości, iż ludzie ci byli lojalnymi urzędnikami (m.in. rządu gubernialnego oraz zarządów poszczególnych miast guberni), nagradzanymi i wyróżnianymi w wielu przypadkach za sumienną służbę, co nie przeszkadzało niektórym z nich uczestniczyć w polskim życiu kulturalnym i społecznym ${ }^{8}$.

Oznacza to, iż inicjatywa powołania w Kaliszu rosyjskiej biblioteki publicznej, jaką przejawił w 1904 roku kaliski gubernator Mikołaj Nowosilcow, mogła spowodować, iż pośród czytelników tej biblioteki znaleźli się także Polacy, pełniący urzędnicze funkcje i utożsamiający się, przynajmniej $\mathrm{w}$ tym czasie, $\mathrm{z}$ wykonywanymi przez siebie zadaniami.

\section{Rosyjska Biblioteka Publiczna}

Rosyjska Biblioteka Publiczna powstała $\mathrm{z}$ inspiracji generał-gubernatora warszawskiego Michaiła Iwanowicza Czertkowa. Jego sugestię powołania biblioteki na potrzeby rosyjskiej społeczności Kalisza entuzjastycznie podchwycił ówcześnie urzędujący gubernator kaliski (notabene wnuk Mikołaja Nowosilcowa, znanego $\mathrm{z}$ antypolskich akcji na Wileńszczyźnie) $)^{9}$. Wzorem stała się istniejąca już od 1881 roku w Płocku rosyjska biblioteka publiczna ${ }^{10}$.

${ }^{8}$ Dobrymi przykładami mogą tu być postacie Stanisława Herburt-Hejbowicza, urzędnika Rządu Gubernialnego Kaliskiego, aktywnego społecznie i wysoko cenionego wśród miejscowej polskiej inteligencji czy też Bolesława Bentkowskiego, redaktora urzędowego czasopisma gubernialnego „Kališskija Gubernskija Vedomosti”, pochowanego na miejskim cmentarzu katolickim w Kaliszu obok syna - oficera Wojska Polskiego. Por. Słownik biograficzny Wielkopolski południowo-wschodniej (ziemi kaliskiej), t. 1-3, Kalisz 1998-2007.

9 Akcja tworzenia w tym czasie rosyjskich księgozbiorów objęła - jak się wydaje - wszystkie gubernie Królestwa Polskiego, skoro w połowie 1903 roku powołano także podobną placówkę w Lublinie. Por. K. Latawiec, Biblioteki rosyjskie w Lublinie w latach 1865-1915 [w:] Lublin a książka, Lublin 2004 s. 448-454.

${ }^{10}$ I. Krasińska, Biblioteki rosyjskie w Królestwie Polskim w latach 1864-1915, Bydgoszcz 2010, s. 509-522. 
Zalecenie powołania biblioteki, skierowane w styczniu 1903 roku do Kalisza, generał-gubernator motywował następująco:

Stworzenie takowych [bibliotek] miało by bardzo wielkie znaczenie dla rozwoju i wzmocnienia interesu rosyjskiego (russkago dieła), a także [...] dla rosyjskiej społeczności, która obecnie w miastach gubernialnych Kraju Przywiślańskiego ma ogromne trudności w posługiwaniu się książkami rosyjskimi ${ }^{11}$.

Mimo iż władze guberni bardzo poważnie podeszły do zalecenia, minął rok, zanim placówka otworzyła swoje podwoje, co nastąpiło 11 stycznia 1904 roku.

Nie ulega wątpliwości, że rosyjska biblioteka publiczna cieszyła się wszechstronnym poparciem władz gubernialnych, które przejawiało się w najrozmaitszy sposób, zaś powagę sprawy wystarczająco podkreśla fakt, iż na czele komitetu biblioteki przez dziesięć lat jej istnienia stały małżonki kolejnych gubernatorów kaliskich.

Znane są niezwykle ciekawe z bibliologicznego punktu widzenia losy tej biblioteki ${ }^{12}$, choć dla potrzeb niniejszego artykułu najistotniejsza wydaje się być informacja, że już w pierwszym roku jej istnienia zarejestrowano 464 czytelników (wobec populacji rosyjskiej na terenie całej guberni kaliskiej w liczbie 1965 osób - dane z 1894 r.), odnotowując jednocześnie 4500 odwiedzin (a zatem blisko 10 na jednego czytelnika). Cyfry te dowodzą, że korzystającymi z biblioteki były przede wszystkim szeroko pojęte kręgi gubernialnego aparatu urzędniczego, który w znacznej części składał się z Polaków.

\section{Inicjatywa bibliotek ludowych}

Jeszcze ciekawsza, choć mało znana, jest rosyjska inicjatywa organizacji bibliotek ludowych, a zatem przeznaczonych dla mieszkańców wsi. W tym miejscu przypomnieć należy główne tezy polityki władz rosyjskich wobec włościaństwa, w której to warstwie społecznej szukano przeciwwagi dla patriotycznie nastawionego ziemiaństwa i inteligencji. Bez wątpienia punktem wyjścia do zrozumienia postawy chłopstwa w czasie powstania styczniowego były działania władz rosyjskich na rzecz uwłaszczenia włościan, a zatem uwolnienia ich od bezpośredniej zależności od dawnej warstwy szlacheckiej.

${ }_{11}$ Archiwum Państwowe w Łodzi. Kancelaria Gubernatora Kaliskiego, vol. 1018, k.nlb.

12 Zob.: K. Walczak, Biblioteki Kalisza i ich miejsce w życiu kulturalnym miasta: 1793-1945, Kalisz 1996, s. 202-206. 
Stosunkowo słaby oddźwięk w kręgach polskiego włościaństwa na wezwania powstańcze 1863 roku jest dobitnym dowodem skuteczności tej polityki ${ }^{13}$.

Inicjatywę tworzenia bibliotek ludowych postrzegać należy jako kolejny element owej polityki, nakierowanej na „oswojenie” włościaństwa z oczekiwaniami władzy nie poprzez brutalną rusyfikację (prowadzoną przecież na dużą skalę w urzędach i szkołach), a stopniowe oswajanie z językiem i kulturą rosyjską, m.in. poprzez działania oświatowe. Taki sens miała podjęta na przełomie wieków decyzja o organizacji sieci bibliotek ludowych, lokalizowanych zazwyczaj w siedzibach gmin i opartych na jednolitym wzorze statutu.

Biblioteki te zawierały księgozbiory rosyjsko-polskie, bowiem zapewne dostrzegano komizm sytuacji, w której, gdy na terenie gminy, nie wspominając o dość powszechnym jeszcze w tym czasie wśród chłopstwa analfabetyzmie, zaledwie kilka osób znało język rosyjski, łożono by środki na organizację księgozbioru wyłącznie rosyjskojęzycznego, z natury rzeczy hermetycznego dla potencjalnej klienteli. Nie znaczy to, że polska część księgozbioru mogła być kształtowana dowolnie; dobór literatury podlegał nadzorowi Komitetu Naukowego przy Ministerstwie Oświaty, dopuszczającego do użytku bibliotecznego tylko wybrane pozycje zarówno rosyjskie, jak i - w szczególności - polskie.

W 1903 roku biblioteki ludowe, na mocy decyzji kuratora Warszawskiego Okręgu Naukowego, zostały przejęte przez istniejące na terenie poszczególnych guberni dyrekcje szkolne, co stało się powodem sporządzenia obszernej dokumentacji działań tych placówek. Brakuje w niej zazwyczaj informacji o wielkości księgozbiorów bibliotecznych, co może świadczyć o jej skromnych zasobach, zwłaszcza według dzisiejszych standardów. Można natomiast uzyskać wiele interesujących informacji o opiekunach tych placówek, którymi zazwyczaj byli wójtowie lub pisarze gminni (a zatem ludzie znający zazwyczaj język rosyjski), rzadziej pisarze sądów gminnych, działacze Komitetów Opieki nad Trzeźwością Ludową czy w końcu nieliczni ziemianie. $\mathrm{Z}$ zachowanej dokumentacji wnioskować można, iż uwaga organizatorów bibliotek ludowych skupiała się nie na efektach działalności owych instytucji a na samym fakcie ich organizacji, czego dowodzą nieliczne dane o wielkości księgozbiorów czy też rezultatach czytelniczych ${ }^{14}$.

${ }^{13}$ Kolejnym dowodem skuteczności działań rosyjskich w odniesieniu do tej warstwy społecznej był słaby oddźwięk wezwań Józefa Piłsudskiego po wkroczeniu oddziałów I Kadrowej na teren Kongresówki w sierpniu 1914 roku.

${ }^{14}$ J. Walicki, Źródła do dziejów książki i czasopiśmiennictwa w Królestwie Polskim (1867-1915) w zespołach kancelarii i gubernatorów na przykładzie guberni kaliskiej i piotrkowskiej. „Acta Universitatis Lodziensis. Folia Librorum" 2006, z. 13, s. 3-20. 
Inicjatywa, forsowana dość mocno w pierwszych latach XX stulecia, straciła impet w czasie niepokojów społecznych lat 1905-1907, później zaś batalię o książkę na wsi wygrały - jak się wydaje - polskie inicjatywy oświatowe i biblioteczne, nabierające od 1906 roku szczególnego przyspieszenia. Tej zmiany można upatrywać w przejściowych ustępstwach ze strony rosyjskiej, w tym liberalizacji cenzury ${ }^{15}$.

\section{Wnioski}

Istnienie rosyjskich bibliotek publicznych na terenie guberni kaliskiej istotnie wzbogaca wiedzę o placówkach bibliotecznych, funkcjonujących na ziemiach polskich w drugiej połowie XIX i pierwszych latach XX wieku. Zauważyć tu trzeba zwłaszcza następujące kwestie:

1. Czas istnienia i zasięg oddziaływania rosyjskich bibliotek o charakterze publicznym dowodzi, iż dopiero trzy ostatnie dekady XIX stulecia przyniosły wyraźną ekspansję żywiołu rosyjskiego na ziemiach prowincji Królestwa Polskiego. Do tego czasu tylko wybrane elementy życia społecznego były poddawane silnemu naciskowi rusyfikacyjnemu, m.in. szkolnictwo.

2. Istotnym ośrodkiem książki rosyjskiej na terenie Królestwa Polskiego była tylko Warszawa. W pozostałych miastach gubernialnych nielicznymi instytucjami tego typu pozostawały drukarnie gubernialne, pracujące przede wszystkim na potrzeby urzędów oraz właśnie bibliotek - zarówno publicznych, jak księgozbiorów organizacji cywilnych i wojskowych, a także instytucji społecznych.

3. Wbrew rozpowszechnionemu przekonaniu, Polacy dość często korzystali z instytucji rosyjskiej książki, choć dotyczy to niemal wyłącznie kręgów urzędniczych, w szerokim znaczeniu tego słowa (włączając w to np. prawników).

4. Książka i biblioteka rosyjska - podobnie jak książka innych mniejszości narodowych - pozostaje znaczącym elementem kształtującym wiedzę

${ }^{15}$ Na terenie guberni kaliskiej szczególną rolę odegrała „Jutrzenka Kaliska” - pismo „dla ludu”, utworzone przez właściciela i redaktora „Gazety Kaliskiej” Józefa Radwana i ukazujące się w latach 1906-1907. Wydawca i redaktor „Jutrzenki” realizował w ten sposób ideę działań na rzecz włościaństwa poprzez uświadomienie narodowe tej warstwy społecznej. Czasopismo, noszące wyraźne ślady narodowo-demokratycznej orientacji wydawcy i skupiające wybitnych przedstawicieli miejscowej inteligencji, nie spełniło jednak pokładanych w nim nadziei. Jego mankamentem był słaby kontakt z odbiorcami i nazbyt „dydaktyczny” charakter przekazywanych treści. K. Walczak, Czasopisma kaliskie XIX i początków XX w. Studium bibliologiczne, Kalisz 2005. 
na temat kultury ziem polskich w czasach zaborów. Stosunkowo mała liczebność tej mniejszości miała jednak znaczną siłę oddziaływania, głównie za przyczyną dominującej roli aparatu władzy. Nie można zatem lekceważyć jej wpływu na losy polskiej kultury, w tym także polskiej książki i biblioteki.

\section{ANEKS $^{16}$}

Каталогъ

РУССКО - ПОЛЬСКИХЬ

НАРОДНЫХЬ ЪИЪЛІОТЕКЬ

Привислинскаго края.

ВЬШУСКИ І, ІІ и III.

(ИЗДАНІЕ КАНЦЕЛЯРІИ ВАРШАВСКАГО ГЕНЕРАЛЬ ГУБЕРНАТОРА).

ВАРШАВА.

Типорафія Канцеляріи Варшавскаго Генералъ - Губернатора. 1898.

\section{ВЫПУСКЬ І.}

I ОТДЪЛЪ, религіозно - нравственныи.

1. O karczmie. Варшава, 1883 г. Изд. 3-е, Червинскаго, ц. $-2 \frac{1}{2} 2$ к.

2. Komu nauka potrzebna. Кс. Мазурекъ. Варшава, ц. - 71/2 К.

3. Rozmowy z Panem Jezusem, utajonym w przenajświętszym sakramenсіе. Варшава, 1887 г. Изд. Немъры, ц. - 5 к.

4. O czystości dziewiczej. Кс. Пельчара. Варшава. 1886 г., ц. - 6 к.

5. Żywot Świętej Barbary. Варшава. 1896 г. Изданіе Немъры, ц. - 5 к.

6. Katechizm rzymsko-katolicki. Варшава. 1897 г. Изданіе Немъры, ц. - 5 к.

7. Żywot Święt. Wincentego à Paulo. Кс. Плещинскій. Варшава. Изданіе Немъры, ц. - 5 к.

8. Żywot Święt. Agnieszki. Варшава. 1886 г. Изданіе Немъры, ц. - 5 к.

9. Żywot Św. Moniki Варшава. 1887 г. Изданіе Немъры, ц. - 2¹/2 к.

10. Żywot Św. Klary z Assyżu. Варшава. 1888 г. Изданіе Немъры, ц. - 5 к.

16 Zachowano oryginalną pisownię katalogu i charakterystyczne dla dokumentu połączenie języków i alfabetów. Dla języka rosyjskiego starano się zachować znaki cyrylicy sprzed reformy pisowni, nie usiłowano także poprawiać transkrypcji polskich nazwisk pisanych (zgodnie z zasadami języka rosyjskiego) fonetycznie. 
II ОТДЪЛЪ популярно - научный.

11. Кагай. С. Вердеревская. С. - Петербургъ. 1893 г., ц. - 8 к.

12. Русскія аладънія въ Средней Азіи. Ю. Кологривовъ. С. - Петербургъ. 1894 г., ц. -10 к.

13. Чай и его польза. Е. Рейнботъ. С. - Петербургъ. 1893 г., ц. - 10 к.

14. Абиссинцы О. Пуцыковичъ С. - Петербургъ. 1896 года, ц. - 5 к.

15. Астраханскій край. С. - Петербургъ. 1897 г., ц. -8 к.

16. Аигличане. О. Пуцыковичъ С. - Петербургъ. 1896 г ., ц. - 5 к.

17. Черногорцы. О. Пуцыковичъ С. - Петербургъ. 1896 года, ц. - 5 к.

18. О гроа Н. Жавотовскій С. - Петербургъ. 1884 г ., ц. - 10 к.

19. Ураль. А. Овсянниковъ. С. - Петербургъ. 1894 г ., ц. - 8 к.

20. Gorzałka. М. Твардовская. Варшава. 1894 г., ц. - 10 к.

21. O zaćmieniach słońca i księżyca. М. Ђрезинскій. Варшава. 1897 г., ц. -10 к.

22. Szkodnictwo w polach, lasach, ogrodach i kary za nie. A. Н. Варшава. 1894 г., ц. -10 к.

23. Maszyny parowe i koleje żelazne. В. Ольшевскій. Варша. 1890 г., ц. $-20 \mathrm{~K}$.

24. Zwierzęta ginące i zaginione. Владиславъ Уминскій. Варшава. 1897 г., ц. -10 к.

25. Brazylja, jej przyroda i mieszkańcy. Павелъ Сосновскій. Варшава. 1892 г., ц. -20 к.

III ОТДЪЛЪ практическихъ свъдній.

26. Пчелы и уходъ за ними. Потъхинъ. Москва. 1891 года, ц. - 10 к.

27. Луга и ихъ улучшеніе. В. Ђажаевъ. Москва, ц. -10 к.

28. Первая помощь до прихода лъкаря. П Ђогословскій Москва, 1885 г. ц. -8 к.

29. Лошадь въ крестьянскомъ хозяйствъ. Москва, 1893 г. ц. -6 к.

30. Сгельная корова. Г. Гуринъ. Москва, 1893 г. ц. -3 к.

31. Саранча и мъры ея истребленія. Линдеманъ, ц. - 10 к.

32. O tem, co to jest ospa. Докторъ А. П. Варшава. 1891 г., ц. -5 к.

33. O suchotach czyli gruźlicy. C. Crep. Варшава. 1890 г., ц. - 21/2 К.

34. Łubin, jego uprawa i pożytek dla gospodarstw włościańskich. Добрскій Варшава. 1890 г., ц. - 4 к.

35. Jak zbierać mierzwę, czyli nawóz, i urządzać gnojownie. Казиміръ Промыкъ. Варшава. 1884 г., ц. - 5 к. 
36. Uprawa kartofli, czyli ziemniaków. Маранъ Правдицъ. Варшава. 1891 г., ц. -10 к.

37. Rośliny groszkowe. А. Снъгоцкій. Варшава. 1895 года, ц. - 10 к.

38. Co robić, gdy kto zachoruje. Іосифъ Зельчакъ. 3-е изданіе. Варшава. 1891 г., ц. -6 к.

39. Rady dla matek o pielęgnowaniu niemowląt. Изд. Колинскаго. Варшава. 1892 г., ц. - 71/2 К.

40. Najpotrzebniejsze wiadomości o cholerze. К. Ьуйвидъ. Варшава. 1894 г., ц. - 10 к.

41. Współpracownicy rolnika - kret, jeż i nietoperz. И. Тарчинскій. Варшава. 1891 г., ц. - 71/2 К.

42. Ratowanie bydlęcia odętego. К. Дуленба. Варшава. 1890 г., ц. - 4 к.

43. Tanie a dobre narzędzia rolnicze dla włościan. К. Дуленба. Варшава. 1890 г., ц. -10 к.

44. Mały podręcznik weterynarii popularnej. Фр. Окнинскій. Варшава. 1895 г., ц. -6 к.

45. Żyto, różne jego gatunki i uprawa. Маріанъ Правдицъ. Варшава. 1893 г., ц. -10 к.

IV ОTДъЛЪ беллетристическій.

46. Алексей Васильевичъ Кольцовъ и его пъсни. Эм. Кислинская. С. Петерб. 1896 г., ц. - 5 к.

47. Пожарный. А. Смирновъ. С. - Петерб. 1896 г., ц. - 5 к.

48. Сгарикъ Никита и его три дочери. А. Съткова. С. - Пегербургъ. 1893 г., ц. -8 к.

49. О севастопольцахъ. А. Супоневъ. С. - Петерб. 1895 г., ц. - 10 к.

50. Христофоръ Колумбъ. С. - Петерб. 1895 г., ц. - 5 к.

51. Извощикъ Климъ. В. Куликова. С.- Петербургъ. 1895 г., ц. - 2 к.

52. Рядовой Саватьевъ. Тютчевъ. Москва. 1891 г., ц. - 5 к.

53. Паденіе Плевны. Изъ военныхъ разсказовъ. С.- Петербургъ. 1879 г., ц. -10 к.

54. Крутиковъ. А. Коваленская. С.- Петербургъ. 1894 года, ц. - 7 к.

55. Аленькій цвъточекъ. С. Аксаковъ. С.- Петерб. 1891 г., ц. - 10 к.

56. Три смерти. Гр. Л. Толстой. Москва. 1890 г., ц. -3 к.

57. Перевозчикъ Ванюшка. Ф. Нефедовъ. Москва. 1893 г., ц. - 3 к.

58. Милость Божія надъ Царемъ - 17 Октября 1888 r. С.- Петербургъ. 1893 г., ц. - 10 К. 
59. Кавказская война и ея герои - Котляревскй и Слъпцовъ. С.Петербургъ. 1879 г., ц. - 12 к.

60. Знаменитый русскій путешественникъ Н. М. Пржеальскій. 1894 г., ц. -10 к.

61. Часовня. Е. Масловъ. С.- Петерб. 1894 г., ц. - 4 к.

62. Пріемышъ. Н. Лухманова. Москва. 1894 г., ц. - 4 к.

63. Михаилъ Васильевичъ Ломоносовъ. А. Филоновъ. С.- Петербургъ. 1894 г., ц. -5 к.

64. Братья. А. Съткова. С.- Петерб. 1891 г., ц. - 5 к.

65. Тоулъ да выплылъ. С.- Петерб. 1894 г., ц. - 8 к.

66. Кавказскій Плънник. Гр. Л. Толетого. С.- Петербургъ. 1884 г., ц. - 10 к.

67. Бирюкъ. И. Тургеневъ. . С.- Петерб. ц. - 4 к.

68. Безпріютная въ тепломъ гнъзышкъ. Б. Е. - Москва. 1896 г., ц. - 6 к.

69. Купецъ Иголкинъ. С.- Петерб. 1895 г., ц. - 4 к.

70. Прекрасная Нивернеза. Харьковъ. 1892 г., ц. - 3 к.

71. Wiesław. Казиміръ Бродзинскій. Варш. 1892 г., ц. - 5 к.

72. Żona z jarmarku. Кл. Юноша. Варшава. 1896 г., ц. - 30 к.

73. Przygody myśliwca. М. Брезинскій. Варшава. 1891 г., ц. - 15 к.

74. Zаја̨с. Кл. Юноша. Варш. 1895 г., ц. - 71/2 к.

75. Przygody Mateusza Jarząbka. В. Тржцинская. Варшава. 1888 г., ц. - 5 к.

76. Bez rodziny. Гектоъ Мало. Перев. Фаустины М. Варшава. 1895 г., ц. -30 к.

77. O Kubie Mądrali. Исерка. Варшава. 1888 г., ц. - 10 к.

78. Sen Marysi I. Ж. Варшава. 1885 г. Немъра, ц. $-2 \frac{1}{2} 2$ к.

79. Czarownica. Эл. Оржешко. Варшава. 1889 г., ц. - 25 к.

80. Dwie żony, albo pokrzywdzony jedynak. Антошка. Варшава. 1891 г., ц. $-71 \frac{1}{2}$ к.

81. Synowa. Бронислава Поравская. Плоцкъ. 1897 г., ц. - 15 к.

82. Antek sierota. Изъ повъсти Терезы Ядвиги „Stacho” передълала Р. М. - Варшава. 1891 г., ц. - 10 к.

83. Dwie siostry służące. Ц. Фальковская. Варшава. 1890 г., ц. - 5 к.

84. Popas w Sławopolu. Сигизмундъ Глогеръ. Варшава. 1891 г., ц. - 15 к.

85. Duchy czarnego boru, czyli kamienne serce. Варшава. Визбекъ, ц. - 10 к.

86. Miłość i pieniądze. Владковскій. Варшава. 1894 г., ц. - 10 к.

87. Lokaj gospodarzem. Ц. Фальковская. Варшава. 1885 г., ц. - 71ำ к.

88. Witek. Людовикъ Немоіовскій. Варшава. 1893 г., ц. -8 к.

89. O Marysi-sierocie. 3. Коверская. Варшава. 1895 г ., ц. - 10 к.

90. Romanowa. Эл. Оржешко. Варшава. 1891 г., ц. - 15 к. 
91. Dwa razy tracona. Іосифъ Грайнертъ. Варшава. 1890 г., ц. - 8 к.

92. Opatrzność Boska. Эдуардъ Б. - Варшава. 1889 г., ц. - 5 к.

93. Pan Protazy. Людовикъ Немоіовскій. Варшава. 1891 г., ц. -8 к.

94. Napomnienia matki. Валентина. Варшава. 1890 г., ц. $-71 \frac{1}{2}$ к.

95. 2 разсказа: 1) O diable co porwał w lesie Bartkowe cielę. 2) Występek sam się karze. Чеславъ Скржижевскій. Варшава. 1895 г., ц. -8 к.

96. Z życia Żakarda. И. Г. - Варшава. 1892 г., ц. - 5 к.

97. Przez morza i stepy. Де - Амичисъ. Варшава. 1897 г., ц. - 5 к.

98. Nieznajomy dobroczyńca. Варшава. Тип. Немъры. 1891 г., ц. -5 к.

99. O Janie Gutenbergu i o tem, jak ludzie nauczyli się pisać i drukować. Антоній Потоцкій. Варшава. 1893 г., ц. - 12 к.

100. Lirnik wioskowy. I. Ж. - Варшава. Тип. Немъры. 1885 г., ц. - 21ำ к. ВЬШУСКЪ II.

І ОТДЪЛЪ, релнгіозно - нравственный.

101. Słowa prawdy o papierosianej modzie i o pijaństwie. Кс. Грабовскій. Варшава. 1886 г., ц. - 12 к.

102. Żywot Świętej Małgorzaty. Бр. П. - Варшава. 1889 г., ц. $-2 \frac{1}{2}$ к.

103. Piekło. Кс. Сегуръ. Варшава. 1892 г., ц. - 20 к.

104. Grzechy jarmarczne. . Кс. Грабовскій. Варшава. 1885 г., ц. - 15 к.

105. Pielgrzymka do Ziemi Świętej. Кс. Клочковскій. Варшава. 1890 г., ц. -15 к.

106. Żywot Najświętszej Panny Maryi. Кс. Брикчинскій. Варшава. 1894 г., ц. -15 к.

107. Rozmowy nauczyciela $\mathrm{z}$ gospodarzami o powinnościach rodziców. М. Малиновскій. Варшава. 1888 г., ц. - 15 к.

108. Domek w Nazaret. Варшава. Тип. Немъры. 1894 г., ц. - 10 к.

109. Wiadomość o życiu Św. Idziego. Варшава. Тип. Немъры. 1893 г., ц. $-5 \mathrm{~K}$.

110. Serce ludzkie w służbie Вożej. Варшава. Тип. Немъры. 1888 г., ц. - 5 к.

II ОТДЪЛЪ, популярно - научный.

111. Расказы о земъ и небъ А. Ивановъ. С. - Петербургъ. 1894 г., ц. - 15 к.

112. О землетрясеніяхъ и горахъ огнедышащихъ. С. Лапченко. С. Петерб. 1876 г., ц. - 10 к.

113. О каменномъ углъ. Я. Никитскій. Москва. 1887 г., ц. - 15 к.

114. Архангельскій край. С. - Петербургъ. 1895 г., ц. - 12 к. 
115. Чго такое соль? Е. Рейнботь. С. - Петербургъ. 1893 года, ц. - 10 к. 116. Китайцы. О. Пуцыковича. С. - Петербургъ. 1896 г., ц. -5 к.

117. Гора Араратъ. Е. Ковалевскій. С. - Петербургъ. 1893 г., ц. - 10 к.

118. Донъ и Донецъ. С. - Петербургъ. 1875 г., ц. - 15 к.

119. Японія. С. - Петербургъ. 1897 г., ц. - 10 к.

120. Mieszkania ludzkie. М. Малиновскій. Варшава. 1891 г., ц. - 15 к.

121. Prawo o służbie w wojsku. Варшава. Изд. Прушинскаго. 1893 г., ц. - 10 к.

122. Skąd się wzięły kamienie na polach naszych? Феликсъ Піотровскій. Варшава. 1894 г., ц. - 10 к.

123. Nasi wrogowie i przyjaciele wśród ptaków. Бржезинскій. 2-е изданіе. Варшава. 1896 г., ц. - 25 к.

124. O wnętrzu ziemi. Мечиславъ Бржезинскій. Варшава. 1894 г., ц. - 25 к.

125. Ciekawe zjawiska w świecie. Казиміръ Промыкъ. Варшава. 1890 г., ц. -15 к.

ІІІ ОТДЪЛЪ, практическихъ свъдъній.

126. Куры и уходъ за ними. Елгинъ. Масква. 1891 г., ц. - 15 к.

127. Какъ спасать и спасаться оть скоропостижяыъ смертедьныхъ случаевъ безъ помощи врачей и знахрей. Н. Глинскій. С. Петербургъ. 1871 г., ц. - 7 к.

128. О сбереженіи здоровья. А. Борисовъ. С. - Петерб. 1894 г., ц. - 12 к.

129. О хлъбныхъ съменахъ и о посъвъ. В. Бажаевъ. Москва, ц. - 6 к.

130. О сохраненіи силы и здоровья. Илинскій. С. - Петербургъ. ц. - 10 к.

131. Какъ Архипъ разбогатълъ? - В. Шимановскій. Москва, 1894 г., ц. -10 к.

132. Poradnik dla kobiet, które chcą być zdrowemi. Іосифъ Зельчакъ. Варшава. 1893 г., ц. -10 к.

133. Pierwsza pomoc w nagłych wypadkach zachorowania. Докт. Буйвидъ. Варшава. 1897 г., ц. - 5 к.

134. Co robić ażeby być zdrowym i długo żyć? Докторъ Іоснфъ Зельчакъ. Варшава. 1895 г., ц. - 10 к.

135. Trzy nauki gospodarskie. Игнатій Лысковскій. Варшава. 1891 г., ц. - 15 к.

136. O hodowli świń, poradnik dla gospodarzy i gospodyń. А. Снъгоцкій. Варшава. 1893 г., ц. - 20 к.

137. Krowy i nabiał. Станиславъ Ревенскій. Варшава. 1885 г., ц. - 12 к.

138. O wściekliźnie. К. Б. - Варшава. 1891 г., ц. - 5 к.

139. Co to są choroby zaraźliwe i jak się od nich chronić. Докторъ Ад. Хелмонскій. Варшава. 1892 г., ц. - 15 к. 
140. Koniczyny i lucerny. А. Снъгоцкій. Варшава. 1895 г., ц. - 15 к.

141. Rośliny okopowe. А. Снъгоцкій. Варшава. 1895 г., ц. - 20 к.

142. Ogrody polne. Эдмундъ Янковскій. Варшава. 1884 г., ц. - 20 к.

143. Konie gospodarskie. Докт. Антоній Баранскій. Варшава. 1896 г., ц. - 12 к.

144. Jak poprawiać łąki. А. Снъгоцкій. Варшава. 1894 г., ц. - 20 к.

IV ОТДЪЛЬ, беллетристическій.

145. О Петръ Великомъ. С. Рождественскій С. - Петербургъ. 1895 г., ц. -15 к.

146. Про капитана Головина. А. Эрленвейнъ. С. - Петербургъ. 1884 г., ц. -20 коп.

147. Рыбы. А. Острогорскій. С. - Петербургъ. 1889 г., ц. - 10 к.

148. Приключеніе Робинзона Крузое. А. Яхонтовъ. С. - Петерб. 1892 г., ц. -10 к.

149. Наваринскій бой. Для солдатъ и народа. С. - Петербургъ. 1882 г., ц. -20 к.

150. Ночь подъ Рождество Христово. Н. Гоголь. 1893 г., С. - Петербургъ. ц. -20 к.

151. Сорочинская ярмарка. Н. Гоголь. С. - Петербургъ. 1893 г., ц. - 15 к.

152. Куликовская битва. Е. Тихомирова. Москва. 1891 года, ц. - 10 к.

153. Взятіе Никополя. С. - Петерб. 1879 г., ц. - 20 к.

154. Какъ воевалъ Петръ Великій со Шведами. І. Сениговъ. С. Петерб. 1893 г., ц. -20 к.

155. Замъчательные русскіе люди - Хабаровъ и Дежневъ. С. Петербургъ. 1881 г., ц. - 15 к.

156. Чесменскій бой. Для солдатъ и народа. С. - Петербургъ. 1893 г., ц. -15 к.

157. Царь - работникъ и учитель. І. Сениговъ. С. - Петербургъ. 1893 г., ц. -15 к.

158. Прерванная вечеринка. А. Острогорскій. С. - Петербургъ. 1889 г., ц. -10 к.

159. Божеское правосудіе. А. Погоскій. С. - Петербургъ. 1880 г., ц. - 20 к.

160. Сибирлетка. А. Погоскій. С. - Петербургъ. 1890 г., ц. - 25 к.

161. Царъ - Миротворецъ Александръ Ш, Императоръ Всероссійскій. Д. Ломанъ. С. - Петербургъ. 1895 г., ц. - 15 к.

162. Путешествіе Его Императорскаго Высочества Наслъдника Цесаревича Великаго Князя Николая Александровича на Востокъ. С. - Петербургъ. 1894 г., ц. - 15 к. 
163. Механикъ - самоучка. И. П. Кулибинъ. Е. Николаева. С. Петербургъ. 1882 г., ц. - 10 к.

164. Капитанская Дочка. А. Пушкинъ. С. - Петербургъ. 1895 г., ц. - 12 к.

165. Разсказы о Севастопольской оборонъ. Гр. Л. Толстой. С. Петербургъ. 1884 г., ц. - 20 к.

166. Параша Сибирячка. Ксавье де - Местръ, С. - Петербургъ, ц. - 10 к.

167. Забытый Рудникъ. - Немировичъ - Данченко. Москва. 1884 г., ц. -15 к.

168. Хижина Дяди Тома. Бичеръ - Стоу. Москва. 1884 года., ц. - 15 к.

169. Дъдушка Крыловъ. А. Филоновъ. С. - Петербургъ. 1894 г., ц. - 10 к.

170. Dziadowski wychowanek. Кл. Юноши. Варшава. 1895 г., ц. - 20 к.

171. Kuba Gąsior. Адольфъ Дыгасинскій. Варшава. 1889 года, ц. - 15 к.

172. Cygańskie dziecko. Р. М. передъл. изъ повъсти Крашевскаго „Chata za wsią". Варшава. 1890 г., ц. - 12 к.

173. Małgorzatka - matusina pieszczoszka. А. Дыгасъ. Варшава. 1890 г., ц. -15 к.

174. Sprawa o płot. Витольдъ Кирторъ. Варшава. 1894 года, ц. - 15 к.

175. Dola Marynki - podrzutka. Антошка. Варшава. 1893 года, ц. - 10 к.

176. O sławnym rycerzu, o Giermku Słowaku i jego ukochanej. Іосифъ Грайнертъ. Варшава. 1894 г., ц. - 10 к.

177. Pan Bartłomiej, czyli tkacze w Komarowie. Юлій Шгарклъ. Варшава. 1896 г., ц. -12 к.

178. W zimowy wieczór. Э. Оржешко. Варшава. 1895 г., ц. - 15 к.

179. Dobre przykłady. Антошка. Варшава. 1894 г., ц. - 5 к.

180. O urwisie Dyrdusiu. Янекъ изъ Бъльца. Варшава. 1889 г., ц. - 10 к.

181. Jak i dla czego po wsiach się żenią. Антошка. Варшава. 1888 г., ц. $10 \mathrm{~K}$.

182. Dwie powiastki: Ofiary. Dobrze zaczął. А. Квятковскій. Варшава. 1889 г., ц. -15 к.

183. Przyjaciel koni. Адоьфъ Дыгасинскій. Варшава. 1895 г., ц. - 15 к.

184. Przygody Robinsona. Ф. М. - Варшава. 1891 г., ц. - 12 к.

185. O Krzysztofie Kolumbie i odkryciu Ameryki. I. Стасякъ. Варшава. 1891 г., ц. -12 к.

186. Powiastki i opowiadania. 3 разсказа: Pod pręgierzem! Niewinność czy zbrodnia? O zbójniku Doroszu. Іосифъ Грайнертъ. Варшава. 1894 г., ц. -12 к.

187. Dwa przeciwne skutki pijaństwa i wstrzemięźliwości. Марія Кевличъ. Варшава. 1884 г., ц. - 15 к.

188. Kubuś sierotka. Фр. Сташицъ. Варшава. 1888 г., ц. - 10 к. 
189. Królowa śniegu. По Андерсену - Игнатій Матушевскій. Варшава. 1891 г., ц. -15 к.

190. O księdzu Boduenie. Докт. Антонъ Пулавскій. Варшава. 1896 г., ц. -6 к.

191. Dwórka. Людовикъ Немоіовскій. Варшава. 1892 г., ц. - 12 к.

192. Praca i uczciwość. Фр. Сташицъ. Варшава. 1876 года., ц. - 15 к.

193. Pan Maciej Trąba. Бронислава Поравская. Плоцкъ. 1897 г., ц. - 15 к.

194. Dwaj przyjaciele, sąsiedzi, koledzy, kumowie. Антошка. Варшава. 1888 г., ц. -10 к.

195. Przygoda Jasia. Эл. Оржешко. Варшава. 1896 г., ц. - 50 к.

196. Przygody Marynki Wójnikówny na Warszawskim bruku. Марія Чеслава. Варшава. 1895 г., ц. - 10 к.

197. Dolina bez wyjścia. Майнъ - Ридъ. Варшава. 1885 года., ц. - 1 р. 20 к.

198. Pobyt w pustyni. Майнъ - Ридъ. Варшава. 1892 года., ц. - 1 р. 20 к.

199. Kręte drogi. По Гофману - Вл. Анчицъ. Варшава. 1880 г., ц. - 40 к.

200. Witek z Kleparza. 3. Моравская. Варшава. 1896 г., ц. - 30 к.

ВЫШУСКЪ III.

І ОТДЪЛЪ, релнгіозно - нравственный.

201. Niezbadane drogi opatrzności Bożej. Кс. Залускій. Варшава. 1897 г., ц. -15 к.

202. Rady kapłana dla ludu. Кс. Грабовскій. Варшава. 1892 г., ц. - 20 к.

203. Czytania o grzechu nieczystości. Кс. Грабовскій. Варшава. 2-е нзд. 1889 г., ц. -30 к.

204. Pamiątka z Częstochowy. Skarbiec Jasnogórski. Варшава. Тип. I. Сикорскій. 1896 г., ц. - 30 к.

205. Dziejowy żywot Jezusa Chrystusa. Кс. Адольфъ Плещинскій. Варшава. 1895 г., ц. - 30 к.

206. O sługach. Варшава. Тип. Немъры. 1894 г., ц. - 10 к.

207. Życie Św. Genowefy. Варшава. 1892 г. Нзд. Гебетнеръ, ц. - 15 к.

208. O spowiedzi. О. Прокопа. Варшава. 1892 г., ц. - 20 к.

209. O pokarmie życia duchownego, czyli o przenajświętszym sakramencie. Пельчаръ. Варшава. 1890 г., ц. - 20 к.

210. Święta Germana. О. Прокопа. Варшава. 1896 г., ц. - 30 к.

211. Żywot. Bł. Bogumiła, Arcybiskupa Gnieźnieńskiego. М. Витановскій Коло. 1895 г., ц. - 15 к. 
II ОТДЪЛЪ, популярно - научный.

212. Ледяное царство и Мертвая земля. С. Максимова. С. - Петербургъ. 1886 г., ц. -20 к.

213. Гдъ на Руси какой народъ живетъ? 2 части. Н. Александровъ. С. Петербургъ. 1884 г., ц. - 20 к.

214. Кавказъ и Закавкаье. В. Желиховская. С. - Петербургъ. 1885 г., ц. -25 к.

215. Чтеніе о Крымъ. - Москва. 1887 г., ц. - 20 к.

216. Отчего бываетъ денъ и ночь - Н. Медеръ. С. - Петербургъ. ц. - 20 к.

217. Міръ Божій. А. Гердъ. С. - Петербургъ. 1883 г., ц. - 40 к.

218. Австралія и Австралійцы. Д. Коропчевскій. Москва. 1889 г., ц. $15 \mathrm{~K}$.

219. О ядовитыхъ и неядовитыхъ змъяхъ. Аникіевъ. С. - Петербургъ. ц. $-10 \mathrm{~K}$.

220. Кавказъ. С. Мечъ. Москва. 1893 г., ц. - 50 к.

221. Owady. М. Бржезинскій. Варшава. 1897 г., ц. - 25 к.

222. O powietrzu i zjawiskach w niem zachodzących. М. Бржезинскій. Варшава. 1896 г., ц. - 35 к.

223. Cuda przemysłu. В. Уминскій. Варшава. 1898 г., ц. - 1р. 20 к.

III ОТДЪЛЪ, практическихъ свъдъній.

224. Руководство къ разведенію плодового сада и уходу за нимъ. А. Соколовъ. Москва. 1895 г., ц. -20 к.

225. Здоровье. А. Савельевъ. С. - Петербургъ. 1888 г., ц. - 35 к.

226. Дерево и его жизнь. Д. Кайгородовъ. Москва. 1882 года, ц. - 15 к.

227. Бесъды о лошади. Н. Кривенко. С. - Петербургъ. 1890 г., ц. - 60 к.

228. О завяданіи зеленей вслъдствіе пораженія ихъ насъкомыяи и мъры истребленія послъднихъ. Линдеманъ, ц. -8 к.

229. Садъ Крестьянина. В. Шимановскій. Москва. 1892 года, ц. - 12 к.

230. O hodowli krów. А. Снъгоцкій. Варшава. 1892 г., ц. - 25 к.

231. Sad przy chacie. Эдмундъ Янковскій. Варшава. 1892 г., ц. - 25 к.

232. Jak zbudowane jest ciało człowieka. М. Бржезинскій. Варшава. 1892 г., ц. - 35 к. (Д л я в з р о сл ы х ъ).

233. Ul gospodarski. Казиміръ Лвицкій. Варшава. 1893 г., ц. - 75 к.

234. Higiena ludowa. Trzeba dbać o zdrowie, aby się ustrzedz choroby. Антошка. Варшава. 1896 г., ц. - 40 к. 
235. Upominek dla matek i gospodyń. Антошка. Варшава. 1896 г., ц. - 25 к. 236. Rośliny pokarmowe. Б. Діаковскій. Варшава. 1895 г., ц. - 35 к.

237. Podręcznik leczniczy. Д-ръ Полякъ. Варшава. 1890 года, ц. - 60 к.

238. Dla zdrowia ludu. Д-ръ Тхуржницкій. Варшава. 1896 года, ц. - 1 p.

239. Gospodarz. Игнатій Лысковскій. Варшава. 1894 г., ц. - 60 к.

240. Ogrodnictwo warzywne, drzew owocowych i krzewów jagodowych, oraz użyteczność tychże. Д-ръ Александръ Карвацкій. Варшава. 1887 г., ц. -60 к.

241. Główne zasady utrzymania zdrowia zwierząt domowych. I. Левандовскій. Нзд. второе. Варшава. 1897 г., ц. -20 к.

242. Karp i jego hodowla w stawach. Антоній Стржелецкій. Варшава. 1896 г., ц. -50 к.

243. Nauka leczenia zwierząt domowych. Рольвесъ. Перев. д-ра А. Сржелецкаго. Варшава. 1893 г., ц. - 1 р.

IV ОТДъЛЪ, беллетристическій.

244. Пахарь. Д. Григоровичъ. С. - Петерб. 1895 г., ц. - 30 к.

245. Басни Крылова. Москва. 1895 г., ц. - 20 к. С. - Петерб. 1891 г., ц. -50 к.

246. Слъпые неразлучники. П. Засодимскій. С. - Петербургъ. 1884 г., ц. -35 к.

247. За Дунаемъ. В. Немировича - Данченко. 2 книги. С. - Петербургъ. 1896 г., ц. -80 к.

248. Майская ночь. Н. Гоголь. С. - Петербургъ. изд. Маркса 1893 г., ц. -15 к.

249. Приключенія капитана Гаттераса. Жюль Вернъ. Москва. ц. - 30 к.

250. Дълатели золота. - Цшоке. Москва. ц. - 25 к.

251. Его Императорское Величество Государь Императоръ Николай Александровичъ, Самодержецъ Всероссійскій. Д. Ломанъ. С. Петербургъ. 1896 г., ц. - 25 к.

252. Ко дню Священнаго Коронованія и Миропомазанія Ихъ Императорскихъ Величествъ Государя Императора Николая Александровича и Государыни Императрицы Александры Феодоровны. Д. Ломанъ. С. - Петербургъ. 1896 года, ц. - 25 к.

253. Земля - кормилица. Горбуновъ - Посадовъ. Москва. 1890 г., ц. -15 к.

254. Въ обходъ Шипки. - Д. Ивановъ. С. - Петербургъ. ц. - 15 к.

255. Послъдній день подъ Шипкой. Д. Ивановъ. С. - Петербургъ. ц. -15 к. 
256. Свътлое Христово Воскесенье. Д. Григоровичъ. С. - Петербургъ. 1884 г., ц. -20 к.

257. Скряга Скруджъ и три добрыхъ духа. Диккенсъ. Казань. ц. - 35 к.

258. Потерянный мальчикъ Вася. Погожева. Москва. ц. - 10 к.

259. Сельско - хозяйственные разсказы. Селивановскій. Москва. 1894 г., ц. -8 к.

260. Гадкій утенокъ. Андерсенъ. ц. - 20 к.

261. Колдунъ. Ою Кеминъ. С. - Петербургъ. 1891 г., ц. - 10 к.

262. Давидъ Ливингстонъ. Москва. 1891 г., ц. - 10 к.

263. Перепелка. И. Тургеневъ. Москва. 1890 г., ц. - 10 к.

264. Апенины и Анды. Де-Амичисъ. С. - Петербургъ. 1887 года, ц. 30 к.

265. Докторъ Дженнеръ. Коровинъ. Москва. 1883 г., ц. - 20 к.

266. Бъжинъ лугъ. И. Тургеневъ. С. - Петербургъ. ц. - 6 к.

267. Подвиги русскихъ. Походы въ Хиву. А. Петровскій. Москва. 1887 г., ц. -10 к.

268. Великіе работники. Фультонъ и Стифенсонъ. С. - Петербургъ. ц. $-15 \mathrm{~K}$.

269. Opowiadanie Kuby Cieluchowskiego o jego emigracji do Brazylji. А. Дыгасинскій. Варшава. 1892 г., ц. - 25 к.

270. Bajki, nie bajki. В. Ольшевскій. Варшава. 1889 г., ц. - 25 к.

271. Młynarz z Zarudzia. Кл. Юноша. Варшава. 1897 г., ц. - 12 к.

272. Przygody myśliwskie młodych osadników w Afryce Południowej. Пo Майнъ - Риду, сост. М. залеская. Варшава. Гебетеръ. 1884 г., ц. - 1 p. 20 к.

273. Młodzi żeglarze, czyli przygody myśliwskie w Ameryce Północnej. Пo Майнъ - Риду, сост. М. залеская. Варшава. Гебетеръ. 1882 г., ц. - 1 р.

274. Przygody podlasiaka w Warszawie. Фр. Сташицъ. Варшава. 1880 г., ц. -15 к.

275. Requiescat In pace. Кс. Хелмицкій. Варшава. 1897 г., ц. - 80 к.

276. Zagrzebani w śniegu. По Гофману сост. Ст. Рженковскій. Варшава. 1893 г., ц. -30 к.

277. Róża z Tannenburga. По Кс. Шмидту сост. Иванъ Кончинскій. Варшава. 1893 г., ц. - 40 к.

278. O życiu i pismach Kazimierza Brodzińskiego. А. Х. Варшава. 1895 г., ц. -10 к.

279. Szlachetne serca. Тереза - Ядвига. Варшава. 1897 г., ц. - 80 к.

280. Bóg nie opuści, kto się nań spuści. По Фр. Гофману состав. Вл. Анчицъ. Варшава. 1898 г., ц. - 50 к. 
281. Spacery z panem Karolem. Конрадъ Држевецкій. Варшава. 1895 г., ц. -60 к.

282. Wygnane bez litości. Антошка. Варшава. 1891 г., ц. - 20 к.

283. Zabawy, gry, zagadki. Сигизмундъ Глогеръ. Варшава. 1891 г., ц. - 15 к.

284. Talisman Janka. Тереза Ядвига. Варшава. 1895 г., ц. - 25 к.

285. Ksiądz Stanisław i Stach. Украинка. Варшава. 1898 г., ц. - 1 р.

286. Jędrek Sokół. Софія Цъшковская. Варшава, 1898 г., ц. - 71ำ к.

287. Na falach Atlantyku. Владиславъ Уминскій. Варшава. 1898 г., ц. - 1 р.

288. Historya o małym i dużym Wojtku i o dobrym Janku. Варшава. 1893 г., ц. -20 к.

\section{Abstract \\ Russian public libraries in Kalisz Province. Contribution to the history of the librarianship at the beginning of the 20th century}

The article provides information about the initiatives of the Russian authorities to organize libraries on the territory of the Kingdom of Poland, an act which aimed at promoting Russian language and culture within Polish society. The author discusses sources of information for the actions taken by the tsarist authorities in the province of Kalisz, and then he presents subsequent initiatives: the foundation and activity of the Russian public library in Kalisz and the history of the people's libraries network that were supplied with mixed collections of Russian and Polish books. To present the collections found in the libraries, which were being established in the municipalities of the Kingdom of Poland, the contents of the catalogue of the Russian-Polish people's libraries, issued at the request of the Governor-General of Warsaw, was included in the appendix, and it provided information about the books - both in Russian and in Polish - authorized for use in these libraries. 